\title{
Massive Acute Pulmonary Embolism in a Pregnant Patient Who Underwent Thrombolytic Treatment in Emergency Service
}

\author{
Acil Serviste Trombolitik Tedavi Uygulanan Gebe Hastada Massif Akut Pulmoner Emboli \\ Sema Bayrak, \\ Vildan Ozer, \\ Selman Yeniocak

\begin{abstract}
1-Karadeniz Technical University, Faculty of Medicine, Department of Emergency Medicine, Trabzon/TURKEY. 2- Rize State Hospital, Department of Emergency Medicine, Rize/TURKEY 3- İstanbul Haseki Training Research Hospital, Department of Emergency Medicine. İstanbul/TURKEY
\end{abstract}

\begin{abstract}
Acute pulmonary embolism is one of the most important preventable mortality causes during pregnancy. In this case report, a 24-week pregnant patient who were diagnosed with Acute pulmonary embolism and who underwent thrombolytic treatment was discussed in the light of a literature review. The 27-year-old female patient, who was pregnant, applied to the emergency service with sudden shortness of breath and chest pain. Since the hemodynamic condition of the patient was unstable, no imaging could be carried out in the radiology unit. As a result of the right ventricular load symptoms detected in bedside Transthoracic Echocardiography, massive Acute pulmonary embolism was diagnosed, and thrombolytic treatment was initiated. Acute pulmonary embolism should be considered in patients who are admitted to emergency services with sudden shortness of breath and chest pain complaints. Patients who are excessively unstable for imaging in the radiology unit should be evaluated quickly with bedside transthoracic Echocardiography, in terms of massive embolism.

$\ddot{O Z Z E T}$

Akut pulmoner emboli (APE), gebelik döneminde en önemli önlenebilir ölüm nedenlerinden birisidir. Bu yazıda APE tanısı alan ve trombolitik tedavi uygulanan 24 haftalık gebe bir hastayı litaratür eşliğinde tartışılmıştır. Gebe olan 27 yaşındaki bayan hasta, ani başlayan nefes darliğl ve gögüs ağrısı şikayetleriyle acil servise müracaat etti. Hastanın hemodinamik durumu unstabil olduğundan radyoloji ünitesinde herhangi bir görüntüleme yapılamadı. Yatakbașı transtorasik ekokardiyografi (EKO)'de sağ ventrikül yüklenme bulguları görülmesi sonucu massif APE tanisı konularak trombolitik tedavi uygulandı.

APE, hemodinamik olarak unstabil olan hastalarda kardiyovasküler acil durumların en yaygın nedenlerinden birisi olup, çok mortal seyreder. Ani başlayan nefes darliğı ve göğüs ağrısı şikayetleriyle acil servise başvuran hastalarda, mutlaka APE düşünülmelidir. Radyoloji ünitesinde görüntüleme yapılamayacak kadar unstabil olan hastalar, hızlıca yatakbaşı transtorasik EKO ile massif emboli açısından değerlendirilmelidir.
\end{abstract}

Keywords:

Acute pulmonary embolism Pregnancy

Thrombolytic treatment

Anahtar Kelimeler:

Akut pulmoner embolizm

Gebelik

Trombolitik tedavi

\section{INTRODUCTION}

Acute Pulmonary Embolism (APE) is approximately 5 times more common in pregnant women than in nonpregnant women of the same age group because of some physiological and anatomical changes. It is one of the most preventable mortality reasons during pregnancy. It ranks the 6th among the causes of maternal mortality with a percentage of $20-30 \%$. For this reason, it is vital to initiate a rapid, effective and timely anticoagulant treatment to prevent APE-related maternal mortality $(1,2)$. In this article, the purpose was to discuss a 24 -week pregnant patient diagnosed with APE who underwent thrombolytic treatment in the light of literature data.

CASE

The 27-year-old female patient, who provided verbal consent for this case report, applied to the emergency service with sudden-onset shortness of breath and chest pain complaints. When the patient arrived, her general condition was moderate, she was conscious and cooperative. Vital signs of the patient are shown in Table1. It was learned that the patient, who had no diseases in her history, had a 24-week pregnancy; and as the gestational period proceeded, she had mild shortness of breath, palpitations and began to feel exhausted faster than before; however, in the last 2-3 days, she had sudden increase in shortness of breath accompanied by chest pain. The patient, who had her first pregnancy, was dyspneic, tachypneic, her skin was pale, she looked anxious, and had prominent jugular venous distension in the physical examination. She also had pretibial edema in bilateral lower extremities, but no difference in diameter could be determined. Systolic murmur was detected in the tricuspid focus in osculation. The patient who had no complaints about pregnancy had natural results in other system examinations.

The patient was taken under observation, and intravenous (i.v.) hydration and nasal $\mathrm{O} 2$ support was initiated. Considering that she might have acute coronary

Correspondence: Sema Bayrak MD. Karadeniz Technical University, Faculty of Medicine, Department of Emergency Medicine.61080 Trabzon - TURKEY E-mail: drsmbyrk@gmail.com

Cite as: Bayrak S, Ozer V, Yeniocak S. Massive Acute Pulmonary Embolism in a Pregnant Patient Who Underwent Thrombolytic Treatment in Emergency Service. Phnx Med J. 2021;3(2):88-90.

Received: 20.12 .2020 Accepted: 11.02.2021 


\section{Bayrak et al.}

Table1: Vital signs of the patient

\begin{tabular}{ll}
\hline Glasgow Coma Scale & 15 \\
\hline Arterial Blood Pressure & $85 / 50 \mathrm{mmHg}$ \\
Pulse Count & $110 / \mathrm{min}$ \\
Body Temperature & $37.6^{\circ} \mathrm{C}$ \\
Respiratory Count & $22 / \mathrm{min}$ \\
Oxygen Saturation & $85 \%$ \\
\hline
\end{tabular}

syndrome, 300mg oral Acetyl Salicylic Acid (ASA) was administered, and $60 \mathrm{mg}$ subcutaneous (SC) Enoxaparin was administered. The blood tests results of the patient are shown in Table 2.

The patient was suspected to have APE. Deep Vein Thrombosis (DVT) was not monitored in the bedside bilateral lower extremity Venous Doppler Ultrasonography (USG). In the bedside Transthoracic Echocardiography (ECO), on the other hand, it was found that Pulmonary Artery Pressure (PAP) was $60 \mathrm{mmHg}$, and the right cardiac cavities were dilated at further levels compared to the left side. The patient was then suspected of having Massive Embolism as her hemodynamic findings was too unstable to undergo Spiral Computed Tomography Pulmonary Angiography (CTPA) or lung ventilation/ perfusion scintigraphy in the radiology unit. Thrombolytic treatment was planned for the patient, who started to become hypotensive, tachycardic, had sweating and a tendency to sleep. Infusion was started with i.v. $100 \mathrm{mg}$ Alteplase/2 hours in intensive care conditions. Infusion with i.v. Heparin was started at $18 \mathrm{IU} / \mathrm{kg} /$ hour dose for the patient who did not develop complications. Partial Thromboplastin Time (aPTT) tracking was with 4-hour interval. The arterial blood pressure of the patient was $110 / 70 \mathrm{mmHg}$, pulse count $85 / \mathrm{min}$, respiratory count was 16/min and O2 saturation 95\%. Prothrombin G20210A heterozygote mutant was detected in further examinations of the patient who was admitted to the chest diseases service. Lifelong anticoagulant treatment was planned for the patient. One week later, she was discharged in a healthy condition with Low-Molecular Weight Heparin (DMAH) treatment.

\section{DISCUSSION}

Among the physiological changes developing in pregnancy, fibrinogen increases with VII, VIII, X and von Willebrand factors, which are coagulation factors. Free protein $\mathrm{S}$ decreases because of the increasing binding protein. The plasminogen activator inhibitor Type I level also increases 5-fold. As a result of these changes, compared to non-pregnant women, the thrombogenic properties increase because of the change in the balance between the procoagulants and anticoagulants. In addition, the Venous Thromboembolism (VTE) development rate increases based on the increased intraabdominal pressure and the pressure of the pregnant uterus to surrounding venous structures (3). Together with these physiological changes in pregnancy in our patient, and with the presence of intraabdominal pressure increase in venous structures, prothrombin (Factor II) G20210A heterozygote mutant was determined in further examinations. In prothrombin (Factor II) G20210A mutation, which is the second most
Table 2: The blood tests results of the patient

\begin{tabular}{ll}
\hline Electrocardiography & Sinus Tachycardia \\
\hline $\begin{array}{l}\text { Serum Electrolyte } \\
\text { Levels }\end{array}$ & Normal \\
C-Reactive Protein & $4.8 \mathrm{mg} / \mathrm{L}$ (range 0-5) \\
Leukocyte & $\begin{array}{l}8715 / \mathrm{mm} 3 \text { (range } 3980-10200 / \\
\mathrm{mm} 3 \text { ) }\end{array}$ \\
Platelet & $242 \times 103 / \mathrm{uL}$ (range 142-424) \\
Hemoglobin & $11.7 \mathrm{~g} / \mathrm{dl}$ (range 14.1-18.1) \\
$\begin{array}{l}\text { D-dimer } \\
\text { High-sensitivity }\end{array}$ & $18.4 \mathrm{mg} / \mathrm{L}$ (range 0-5) \\
Troponin I & $\mathrm{ng} / \mathrm{L}$ (range 0-11.6) \\
Arterial Blood Gas & $\mathrm{pH}^{2} 7.51$ \\
Analysis & $\mathrm{pO}^{2}: 51.9 \mathrm{mmHg}$ \\
& $\mathrm{pCO}^{2}: 31.8 \mathrm{mmHg}$ \\
& $\mathrm{HCO}^{3}: 23 \mathrm{mEq} / \mathrm{L}$ \\
\hline
\end{tabular}

common hereditary risk factor after the gene encoding FXIIIa, the prothrombin concentration increases with the replacement of Guanin $(\mathrm{G})$ by Adenine (A) in the prothrombin gene 20210 nucleotide. In this case, the venous thrombosis risk increases by 2.8 times, and the VTE risk due to pregnancy increases by 15 times (4).

APE symptoms are difficult to diagnose because of their confusion with symptoms and findings that develop in later pregnancy. Although some scoring systems like modified Wells and modified Geneva are used for the diagnosis of $\mathrm{PE}$ in pregnancy, doubting the clinical signs and findings it is necessary to assume that the patient may have VTE. Swelling and discomfort in the legs, dyspnea (70\%), tachypnea, and tachycardia are common complaints and symptoms in pregnancy. Pain, swelling and/or erythema, and increased heat and sensitivity in lower extremities suggest DVT (5). Our patient had pretibial edema in lower extremities, but the difference in diameter could not be detected. No VTE was detected in the bilateral lower-extremity Venous Doppler USG. The respiratory symptoms could have developed because of the anemia and/or increased intraabdominal pressure detected in the examinations. However, the sudden development of the complaints made us suspect APE. The most frequentlydetected ECG anomaly of APE patients is the sinus tachycardia with a rate of $52.5 \%$ (6). Sinus tachycardia was monitored in the ECG of our patient, which was compatible with the literature.

The levels of D-dimers, which are the fibrin destruction products, can be used in the diagnosis of APE. Low D-dimer levels in non-pregnant patients help to exclude the PE diagnosis at a high rate. However, although its negative predictive value is high in pregnant women, its positive predictive value is low because D-dimer levels increase physiologically throughout pregnancy (7). Since the respiratory alkaloses that will support APE in arterial blood gas analysis are also among the physiological respiratory changes that can be seen during pregnancy, they are not diagnostic either (8). The D-dimer level of our patient was high, which was in line with the literature; however, since this elevation could be physiological, it was 


\section{Phnx Med J. July 2021, Volume 3 No 2}

not diagnostic. There was also respiratory alkaloses in the arterial blood gas analysis, which could be physiological or due to APE.

The most important problem in pregnancy is the selection of the examinations to be performed for the diagnosis of APE. In pregnant women with suspected APE, Bilateral Lower Extremity Venous Doppler USG is performed as the first-line examination to protect the patient and fetus from exposure to radiation. If the VTE is negative, further examinations are needed. Chest X-ray should be performed to evaluate alternative diagnoses in the further examination. If there are no signs of pulmonary $\mathrm{x}$-rays, Ventilation/Perfusion (V/P) Scintigraphy is the first diagnostic method to be chosen (5). However, spiral CTPA is performed for patients who have pathologies like Chronic Obstructive Pulmonary Disease (COPD) and emphysema, which can affect the Scintigraphy results of the graph. The most important problem in Spiral CTPA is the dose of the radiation to which the fetus will be exposed. In previous studies, it was shown that the dose of radiation to which the fetus will be exposed is lower than in scintigraphy (9). Since there are no comparative studies for the use of Magnetic Resonance (MR) Angiography in pregnant women, its safety has not yet been proven. Because the long-term fetal effects of Gadolinium are not known, it is relatively contraindicated (10). Since her hemodynamic findings were unstable, no imaging was performed in the radiology unit for our patient.

The diagnostic examination that are planned for hemodynamically unstable patients is bedside Transthoracic Echocardiography (ECO). It provides the opportunity for a safe, fast and noninvasive diagnosis to evaluate the suspected massive PE. In Massive Emboli, the right atrium and ventricle are significantly enlarged compared to the left, and the interventricular septum is seen to have shifted towards the left ventricle in ECO. In addition, PAB is measured in increased quantity. In APE, the right ventricular dysfunction is associated with poor prognosis, and plays a decisive role in clinical treatment (11). Our patient underwent bedside Transthoracic ECO. Right cardiac cavities were measured to be dilated as high together with right ventricle dysfunction, and PAB was also high. The patient was accepted to have massive embolism, and thrombolytic treatment was started in intensive care conditions, as stated in the literature. Alteplase, which is a Tissue Plasminogen Activator (tPA) that does not cross the placenta, is recommended in European APE Guide for pregnant women planned to receive thrombolytic (12). After Alteplase infusion, our patient was admitted to the Chest Diseases Service without complications. After one week, the patient was discharged with healing with lifelong use of anticoagulants.

\section{CONCLUSION}

APE is one of the most common cardiovascular emergency causes in patients who are hemodynamically unstable, and its progression is quite mortal. APE should be considered in patients admitted to emergency services with sudden shortness of breath and chest pain complaints. Patients who are too unstable to undergo imaging in radiology unit should be evaluated quickly in terms of Massive Embolism with bedside Transthoracic ECO. It is possible to reach positive results with early diagnosis and effective treatment.

Conflict of Interest: No conflict of interest was declared by the authors.

\section{REFERENCES}

1. Mac KAP, Berg CJ, Liu X, Duran C, Hoyert DL. Changes in pregnancy mortality ascertainment: United States, 1999-2005. Obstetrics and gynecology 2011; 118(1): 104-110.

2. Pillny M, Sandmann W, Luther B, Muller BT, Tutschek B, Gerhardt A, et al. Deep venous thrombosis during pregnancy and after delivery: indications for and results of thrombectomy. Journal of vascular surgery 2003; 37(3): 528-532 .

3. Bremme KA. Haemostatic changes in pregnancy. Best practice \& research Clinical haematology 2003; 16(2): $153-168$.

4. Rey E, Kahn SR, David M, Shrier I. Thrombophilic disorders and fetal loss: a meta-analysis. Lancet 2003; 361: $901-908$.

5. Leung AN, Bull TM, Jaeschke R, Lockwood CJ, Boiselle PM, et al. An official American Thoracic Society/Society of Thoracic Radiology clinical practice guideline: evaluation of suspected pulmonary embolism in pregnancy. Am J Respir Crit Care Med 2011; 184(10): 1200-1208.

6. Bozorgmehr R, Pishgahi M, Mohaghegh P, Bayat M, Khodadadi P, et al. Relationship between Thrombosis Risk Factors, Clinical Symptoms, and Laboratory Findings with Pulmonary Embolism Diagnosis; a Cross-Sectional Study. Arch Acad Emerg Med 2019; 7(1): 41.

7. Kovac M, Mikovic Z, Rakicevic L, Srzentic S, Mandic V, et al. The use of D-dimer with new cutoff can be useful in diagnosis of venous thromboembolism in pregnancy. Eur J Obstet Gynecol Reprod Biol 2010; 148(1): 27-30.

8. Yaşar Z, Talay F. The Management of Tromboembolic Diseases in Pregnancy. Abant Medical Journal 2015; 4(3): 302-308.

9. Winer-Muram HT, Boone JM, Brown HL, Mabie WC, Lombardo GT. Pulmonary embolism in pregnant patients: fetal radiation dose with helical CT. Radiology 2002; 224: 487-492.

10. International Conference on Harmonisation; draft guidance on E2F Development Safety Update Report; availability. Notice. Fed Regist 2008; 73(151): 45462-45463.

11. Rodrigues AC, Guimaraes L, Guimaraes JF, Monaco C, Cordovil A, et al. Relationship of clot burden and echocardiographic severity of right ventricular dysfunction after acute pulmonary embolism. Int J Cardiovasc Imaging 2015; 31(3): 509-515.

12. Konstantinides SV, Torbicki A, Agnelli G, Danchin N, Fitzmaurice D, et al. 2014 ESC guidelines on the diagnosis and management of acute pulmonary embolism. Eur Heart J 2014; 35: 3033-3069. 